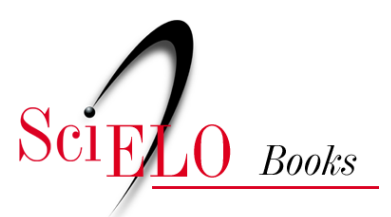

\title{
Reflexões \\ A geração alt+tab vai às ruas
}

\author{
Nelson De Luca Pretto
}

PRETTO, N.D.L. A geração alt+tab vai às ruas. In: Educações, culturas e hackers: escritos e reflexões [online]. Salvador: EDUFBA, 2017, pp. 138-139. ISBN: 978-85-232-2019-8.

https://doi.org/10.7476/9788523220198.0029.

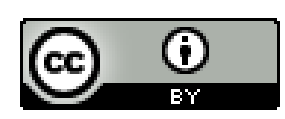

All the contents of this work, except where otherwise noted, is licensed under a Creative Commons Attribution $\underline{4.0 \text { International license. }}$

Todo o conteúdo deste trabalho, exceto quando houver ressalva, é publicado sob a licença Creative Commons Atribição 4.0.

Todo el contenido de esta obra, excepto donde se indique lo contrario, está bajo licencia de la licencia Creative Commons Reconocimento 4.0. 


\section{A geração alt+tab vai às ruas}

Mais de 2 milhões de brasileiros manifestaram-se ruidosamente nas ruas durante o último mês de junho de 2013. O que querem mesmo esses jovens nas ruas? Essa tem sido a pergunta de muitos, especialmente políticos e mídia, na tentativa de, por um lado, entender e, por outro, desqualificar as recentes manifestações. Fala-se de não objetividade nas reivindicações, do excesso de bandeiras e da falta de lideranças.

Nem sempre é necessário ter clareza ou unificar bandeiras de luta. A falta de "objetividade" (as aspas aqui são fundamentais!) foi sempre motivo de estranhamento de muitos acadêmicos, da mídia e, por consequência ou não, da população em geral: o que querem essas meninas e meninos?

Lembro que foi assim também quando do início do Fórum Social Mundial (FSM) em 2001, que reuniu cidadãos do mundo inteiro para, já naquele momento, protestar contra tudo e todos. Havia uma sensação generalizada - que, aliás, é a mesma de hoje - de que tudo estava para ser resolvido e uma forma de desqualificar aquelas iniciativas era dizer que faltava foco e objetividade nas discussões e propostas. Lembro-me de estar num dos primeiros Fóruns, em um auditório superlotado, deliciando-me com depoimento de Eduardo Galeano (das Veias abertas da América Latina, lembra?!) que iniciava sua fala com uma pichação encontrada em um muro de uma cidade da América Latina: "quando achamos todas as respostas, mudaram a pergunta”.

É o que de novo ocorre no país e no mundo. Os métodos, as práticas, a política, a economia, tudo está a merecer outro olhar. Não temos ainda as respostas, pois a pergunta mudou!

Impressionantes imagens publicadas pelo New York Times, de 21 de junho de 2013, mostram-nos aquilo que vimos nas ruas: a diversidade de reivindicações ("gosto de mulher, e daí?", "abaixo a fifa", "não é pelos 0,20", "passe livre, "mais saúde”, "mais educação”, entre tantas).

Diferentes bandeiras, diferentes visões de mundo e tudo isso é muito bom esteja nas redes e nas ruas! 
Cobrar objetividade é matar o movimento. Objetividade é algo que foi construído ao longo da história da humanidade e não um conceito absoluto e concreto desde sempre. Além do que - e talvez mais importante do que tudo isso - a diversidade de bandeiras, literalmente falando e não só metaforicamente, corresponde à rica diversidade da população e da política brasileira. Um governo que se preze tem que considerar que essas diferenças são mais do que importantes. Elas são a base fundamental de existência da sociedade e é para isso que se tem que buscar formas de governar.

Essa geração, de qualquer idade, com uma dezena de telas abertas ao mesmo tempo, usando as teclas alt+tab para navegar simultaneamente em todas elas, está, agora e literalmente, navegando pelas ruas das cidades com a mesma intimidade com que navegam pelas telas. "Saímos do Facebook", dizia um cartaz. Estamos na rua, complemento. Na rua com os facebooks, orkuts, twitters, instagrams e tudo mais.

Não sejamos simplistas. O momento atual é complexo, como também o é a vida.

E complexo não é sinônimo de complicado. A complexidade exige um olhar, ou melhor, múltiplos olhares, com rigorosa atenção.

Educação, claro, está entre as bandeiras. Mas que educação?!

Certamente precisamos de mais recursos para a educação, mas não apenas para fazer mais do mesmo. É urgente que superemos definitivamente as atuais concepções de educação que formam para a linearidade e não para a complexidade.

E isso não é pouco.

Publicado, em versão reduzida, na revista Muito, jornal A Tarde, em 14 de julho de 2013 